\title{
Agronomic divergence of sorghum hybrids for silage yield in the semiarid region of Paraiba $^{1}$
}

\author{
Thiago Carvalho da Silva², Edson Mauro Santos ${ }^{3}$, José Augusto Gomes Azevedo4, Ricardo \\ Loiola Edvan ${ }^{5}$, Alexandre Fernandes Perazzo ${ }^{3}$, Ricardo Martins Araújo Pinho ${ }^{3}$, José Avelino \\ Santos Rodrigues ${ }^{6}$, Divan Soares da Silva ${ }^{3}$
}

\footnotetext{
${ }^{1}$ Financiado pelo Conselho Nacional de Desenvolvimento Científico e Tecnológico (CNPq).

2 Departamento de Zootecnia - Universidade Federal de Viçosa.

${ }^{3}$ Departamento de Zootecnia - Centro de Ciências Agrárias - Universidade Federal da Paraíba.

${ }^{4}$ Departamento de Ciências Agrárias e Ambientais - Universidade Estadual de Santa Cruz.

${ }^{5}$ Departamento de Zootecnia - Universidade Federal do Ceará.

${ }^{6}$ Embrapa Milho e Sorgo.
}

\begin{abstract}
The objective of this study was to evaluate the agronomic divergence of 25 sorghum hybrids (Sorghum bicolor L. Moench) in the semiarid region of Paraiba. A randomized block design with three replications was used for evaluation of plant height (PH), total natural matter production (TNMP) and total dry matter production (TDMP) and the percentage of components of DM (panicle, leaf blade, stem and dead matter) of the following hybrids: 866005, 866019, 866033, 866034, 866035, 866036, 866037, 866040, 866041, 866042, 866043, 866044, 870025, 870031, 870035, 870041, 870051, 870067, 870081, 870085, 870095, 1F305, BRS 610, Volumax, and XBS60329. Hybrid 1F305, followed by hybrid 866034, presented the highest average PH. There was a range from 7.679 to $20.948 \mathrm{~kg} / \mathrm{ha}$ (average of 13,799 kg/ha) for TDMP. Hybrids 1F305, BRS 610 and Volumax presented less potential, and hybrids 866,041 and 866,042 were the most productive. Based on cluster analysis and subjective cut in $50 \%$ of dissimilarity, it was possible to establish four hierarchical groups, from which two stood out concerning productive characteristics. The group formed by hybrids Volumax, BRS 610, and XBS60329 presented lower averages for yield and lower percentage of panicle. Hybrids 866041 and 866042 show a higher total dry matter production, with values around $20,000 \mathrm{~kg} / \mathrm{ha}$.
\end{abstract}

Key Words: agronomic characteristics, dry matter, forage, panicle

\section{Introduction}

The Northeast region of Brazil has approximately 70\% of its area included in the semiarid region, characterized by climatic conditions that cause the seasonal variation in forage production, which is used as staple diet of ruminants.

Given this situation, the sorghum crop may be a viable option, due to its xerophilous characteristics, yield potential, deep root system, and its multivariate use (Tabosa et al., 1993). Among the advantages of using sorghum, the high total dry matter production (TDMP), resistance to water deficit situations and short summer periods, through water use efficiency, low soil fertility requirement, and possible use of regrowth stand out (Mello et al., 2003; Portugal et al., 2003, Silva et al., 2004, Monteiro et al., 2004, Rezende et al., 2005).

According to Zago (1991), the agronomic characterization of numerous genetic materials available on the market is essential for obtaining sorghum silage of high production and nutritional value. This characterization is based on the percentage of participation and chemical composition of the main anatomical structures of the plant, defining an average profile of each genetic material.

Gomes et al. (2006), when evaluating the agronomic characteristics of sorghum cultivars in the state of Ceará, Brazil, observed values of plant height ranging from 1.52 to $4.11 \mathrm{~m}$ and TDMP ranging from 6884.0 to $14830.0 \mathrm{~kg} / \mathrm{ha}$. Tabosa et al. (2002) also evaluated 20 sorghum varieties in different regions of the states of Pernambuco and Alagoas, and observed mean values ranging from 3,040 to $15,750 \mathrm{~kg} / \mathrm{ha}$.

Considering this information, this study aimed to evaluate the agronomic divergence of 25 sorghum hybrids for silage yield in the semiarid region of Paraíba.

\section{Material and Methods}

The experiment was conducted at the experimental station of Instituto Nacional do Semiárido (INSA), in Campina Grande, Paraiba state, and Laboratório de Nutrição Animal do Centro de Ciências Agrárias of Universidade Federal da Paraíba (UFPB). Campina Grande city is located 
at $551 \mathrm{~m}$ of altitude, with the following geographical coordinates: $35^{\circ} 52^{\prime} 52^{\prime \prime}$ west longitude and $07^{\circ} 13^{\prime} 50^{\prime \prime}$ south latitude. According to Koppen, the climate of the area is of type As (hot and humid with rainfall occurrences from fall to winter). With dry seasons ranging from 5 to 6 months, the city is in a transition zone between Agreste and Cariri, regions from Paraiba. Soil from experimental area was classified as Planosol. The climatic data during the experimental period are shown in Table 1 and Figure 1.

The experimental design consisted of randomized blocks with with three replicates. Treatments were 25 sorghum hybrids, 21 of them belonging to the sorghum breeding program at Embrapa Milho e Sorgo: 866005, 866019, 866033, 866034, 866035, 866036, 866037, 866040, 866041, 866042, 866043, 866044, 870025, 870031, 870035, 870041, 870051, 870067, 870081, 870085, 870095, and four commercial hybrids: 1F305, BRS 610, and Volumax XBS60329.

Table 1 - Climatic variables recorded in the meteorological station of Instituto Nacional do Semiárido during the experimental period

\begin{tabular}{lccccc}
\hline & April & May & June & July & August \\
\hline Rainfall occurrence (days) & 7 & 10 & 7 & 15 & 10 \\
Rainfall $(\mathrm{mm})$ & 138.2 & 57.6 & 88.8 & 100.5 & 81.74 \\
Average temperature $\left({ }^{\circ} \mathrm{C}\right)$ & 25.5 & 24.4 & 23.1 & 22.7 & 22.3 \\
\hline
\end{tabular}

The sowing of grass was performed manually on April 18 , 2009, in plots of $4.9 \mathrm{~m}^{2}(4.9 \times 1.0 \mathrm{~m})$, with a space of $70 \mathrm{~cm}$ between rows and, 30 days after planting, the thinning process was performed, conserving density of 12 plants per linear meter. The experimental plot consisted of seven rows of $1 \mathrm{~m}$ length spaced $0.70 \mathrm{~m}$, with a total area of $4.90 \mathrm{~m}^{2}$. The observations were taken in an area of $1.4 \mathrm{~m}^{2}(2.8 \times 0.5 \mathrm{~m})$, corresponding to the four central rows, discounting $25 \mathrm{~cm}$ from each extremity.

A fertilization based on the soil chemical properties of the experimental area was conducted, using $100 \mathrm{~kg} / \mathrm{ha}$ of nitrogen in the form of ammonium sulfate and $60 \mathrm{~kg} / \mathrm{ha}$ of $\mathrm{P}_{2} \mathrm{O}_{5}$, in the form of superphosphate. The application of nitrogen was divided - 50\% applied in the thinning process and the remaining 15 days after the thinning process, whereas phosphorus was applied during the planting process. It was not necessary to apply potassium because of the high content of this nutrient in the soil (Table 2).

The crop was harvested when the grains were in the dough stage. The four central rows were harvested and $25 \mathrm{~cm}$ from each extremity were not considered. As the experimental hybrids reached the point of harvest on different days, three separate harvests were done. The cycle from planting to harvest was of 98, 104, and 131 days for first, second and third harvest, respectively. In the first, the hybrids picked were 866042, 866043, 866044, 870025, 870035, 870041, 870051, 870067, and BRS 610; in the second

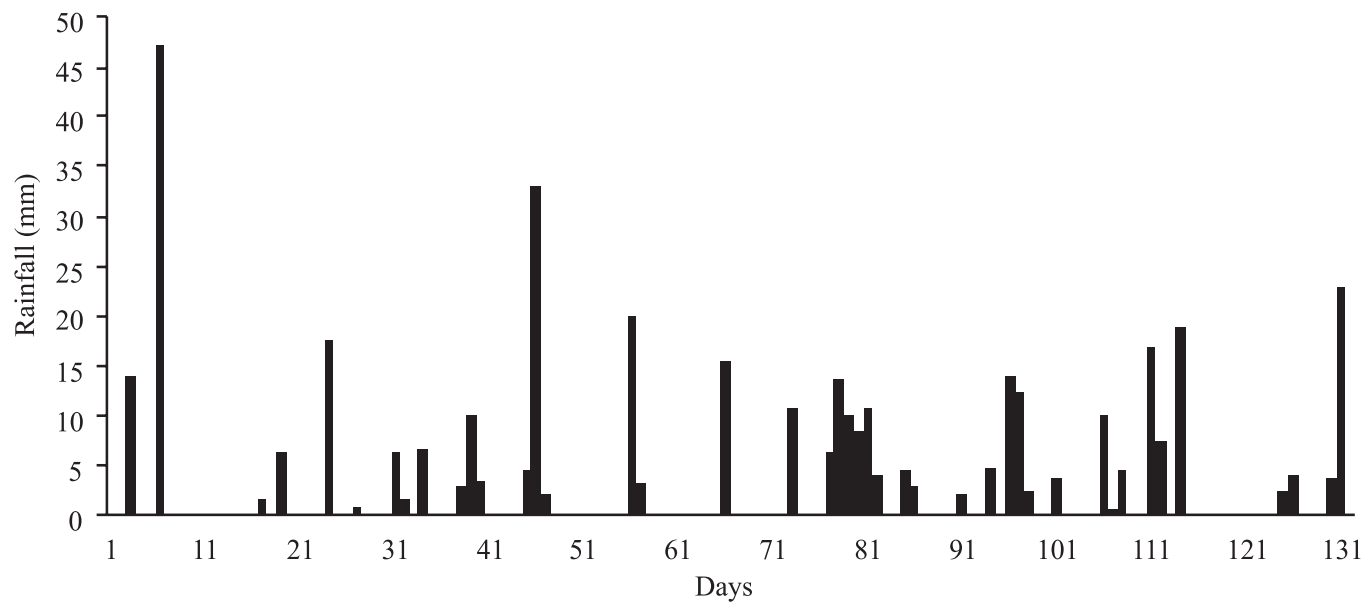

Figure 1 - Distribution by ten days of rainfall at the experimental station of Instituto Nacional do Semiárido from April to August 2009.

Table 2 - Soil chemical attributes of the area where the experiment was conducted, at the experimental station of Instituto Nacional do Semiárido

\begin{tabular}{|c|c|c|c|c|c|c|c|c|c|c|c|c|}
\hline $\mathrm{pH}$ & P & $\mathrm{K}^{+}$ & $\mathrm{Na}$ & $\mathrm{H}^{+}+\mathrm{Al}^{+3}$ & $\mathrm{Al}^{+3}$ & $\mathrm{Ca}^{+2}$ & $\mathrm{Mg}^{+2}$ & SB & CTC & V & $\mathrm{m}$ & MO \\
\hline $\mathrm{H}_{2} \mathrm{O}$ & & & & & & $10 l_{c} / d$ & & & & & & $\mathrm{~g} / \mathrm{kg}$ \\
\hline 5.44 & 17.00 & 153.53 & 0.39 & 0.00 & 0.05 & 2.30 & 0.60 & 3.68 & 3.68 & 100 & 1.34 & 11.8 \\
\hline
\end{tabular}

R. Bras. Zootec., v.40, n.9, p.1886-1893, 2011 
one, hybrids 866005, 866019, 866033, 866034, 866035, 866036, 866037, 866040, 866041, 870031, 870081, 870085, 870095, Volumax and XBS60329; and in the last one, hybrid 1F305. The evaluation cut was done manually, with knives. For purposes of evaluation, the production of $2 \mathrm{~m}$ of furrow per plot was considered, proceeding initially to the counting of the number of plants per meter.

The variables evaluated were: plant height $(\mathrm{PH})$, total natural matter production (TNMP) and total dry matter production (TDMP) in $\mathrm{kg} / \mathrm{ha}$, and the percentage of DM components: panicle, leaf, stem, and dead matter. Material collected from each plot was separated into panicles, leaf, stem, and dead matter, weighing each fraction separately. A subsample of each fraction was oven-dried $\left(65^{\circ} \mathrm{C}\right)$ until reaching constant weight, for DM determination. Following this, total biomass of panicle, leaf blade, stem and dead matter were estimated. TDMP was estimated by the product of TNMP by DM content.

The results obtained were subjected to analysis of variance and, when appropriate, the Scott-Knott test at $5 \%$ probability $(\mathrm{P}<0.05)$ was performed to compare means of each treatment, using the SAEG software, version 8.0, (UFV, 2000). Test application proposed by Scott \& Knott (1974) is a clustering method that unlike other tests of multiple comparison of means eliminate the ambiguity and separates the means of treatments in homogeneous groups to facilitate interpretation, especially when working with a large number of treatments (Santos et al., 2001).

The multivariate analyses were performed using the SAEG software, version 8.0 (UFV, 2000) as a tool, in which the hierarchical cluster analysis was performed through the Ward method (Johnson \& Wichern, 1992), adopting the Euclidean distance as a basic measure of dissimilarity, with the with standardized data. As discriminatory features, plant height, production of natural matter and total dry matter, and percentage of components of DM, panicle, leaf, stem, and dead matter were taken. The hierarchical techniques are the most widespread (Siegmund et al., 2004) in these methods: individuals are grouped by a process that is repeated at various levels until the setting of a dendrogram or tree diagram. Two stages are involved in this process: one that refers to the estimation of a measure of similarity or dissimilarity between individuals and the second, the adoption of a technical training group (Santana \& Malinovsky, 2002).

\section{Results and Discussion}

There were differences $(\mathrm{P}<0.05)$ between average plant height, ranging from 1.97 to $2.62 \mathrm{~m}$ (Table 3). Hybrid 1F305 presented the highest $(\mathrm{P}<0.05)$ average plant height, followed by hybrid 866034. Hybrids 866033, 866041, 866042, 870051 , and 870081 formed a group with mean values

Table 3 - Mean values of plant height, total yields of natural and dry matters of 25 hybrid sorghum grown in the semiarid region of Paraiba

\begin{tabular}{|c|c|c|c|}
\hline Hybrid & Plant height $(\mathrm{m})$ & Total natural matter production (kg/ha) & Total dry matter production $(\mathrm{kg} / \mathrm{ha})$ \\
\hline 866005 & $2.00 d^{*}$ & $44,233.59 a$ & $15,496.76 b$ \\
\hline 866019 & $2.00 \mathrm{~d}$ & $44,179.96 a$ & $15,661.56 b$ \\
\hline 866033 & $2.11 \mathrm{c}$ & $33,694.74 b$ & $11,724.55 c$ \\
\hline 866035 & $1.98 \mathrm{~d}$ & $42,277.92 \mathrm{a}$ & $14,746.92 b$ \\
\hline 866036 & $1.98 \mathrm{~d}$ & $40,909.15 a$ & $16,522.67 b$ \\
\hline 866037 & $2.07 \mathrm{~d}$ & $37,583.88 \mathrm{a}$ & $13,427.38 \mathrm{c}$ \\
\hline 866042 & $2.13 c$ & $50,069.69 a$ & $20,948.70 a$ \\
\hline 866043 & $2.07 \mathrm{~d}$ & $41,993.80 \mathrm{a}$ & $15,397.97 b$ \\
\hline 866044 & $2.00 \mathrm{~d}$ & $40,890.29 a$ & $11,369.80 \mathrm{c}$ \\
\hline 870025 & $2.07 \mathrm{~d}$ & $31,383.03 b$ & $12,881.47 \mathrm{c}$ \\
\hline 870031 & $2.03 \mathrm{~d}$ & $38,246.13 \mathrm{a}$ & $17,715.74 b$ \\
\hline 870035 & $2.03 \mathrm{~d}$ & $31,256.71 b$ & $13,394.51 \mathrm{c}$ \\
\hline 870085 & $1.98 \mathrm{~d}$ & $29,952.94 b$ & $12,818.33 c$ \\
\hline 870095 & $1.99 \mathrm{~d}$ & $27,371.57 \mathrm{~b}$ & $12,010.68 c$ \\
\hline $1 F 305$ & $2.62 \mathrm{a}$ & $35,516 \cdot 07 b$ & $12,983.20 \mathrm{c}$ \\
\hline BRS 610 & $2.00 \mathrm{~d}$ & $26,459.17 b$ & $7,679.87 d$ \\
\hline Volumax & $2.07 d$ & $22,529.79 b$ & $7,875.06 \mathrm{~d}$ \\
\hline XBS60329 & $2.03 \mathrm{~d}$ & $24,607.15 b$ & $9,865.51 \mathrm{~d}$ \\
\hline Mean & 2.07 & $35,709.55$ & $13,799.30$ \\
\hline CV (\%) & 2.68 & 16.82 & 16.85 \\
\hline
\end{tabular}

* Means followed by the same letter in column do not differ among themselves by Scott-Knott test at $5 \%$ probability, CV = coefficient of variation. 
ranging from 2.10 to $2.12 \mathrm{~m}$ of height and the others showed height below $2.10 \mathrm{~m}$ ( $\mathrm{P}>0.05)$.

In general, plant height values, although different, are within an average range of approximately $2.0 \mathrm{~m}$, except for 1F305. The values of average height observed for hybrids 1F305 and Volumax were higher than those found by Silva et al. (2007), of 1.42 and 1.34 m respectively.

Plant height is a trait that can be highly correlated with production, because larger plants tend to accumulate more mass in a longer period of time, as observed by Flaresso et al. (2000), who noted that late-maturing sorghum hybrids showed greater height and greater DM production. However, shorter plants may have high yields in shorter time, due to the panicle participation, increasing the DM content. In this study, the correlation between plant height and TNMP or TDMP was low, with values of 0.1003 and 0.1544 , respectively.

According to Zago (1991) and Pereira et al. (1993), DM content increases faster in midsized and down-sized hybrids, due to the greater panicle participation in total DM, as observed in this study, where hybrids of intermediate size had the highest yields (Table 3). In the sorghum, the potential for DM production increases and panicle percentage decreases with the increase in plant height, and its rate of decline is smaller in midsized and down-sized hybrids, when plant height exceeds $3 \mathrm{~m}$ (Zago, 1991).

Among the characteristics evaluated,TNMP presented a difference $(\mathrm{P}<0.05)$ among the hybrids under study, ranging from 22,529 to 50,069 kg/ha (average of 35,709 kg/ha), with the formation of two groups, a more productive one ( $\mathrm{P}>0.05$ ), with higher production of natural matter, superior to $37,000 \mathrm{~kg} / \mathrm{ha}$, and another with natural matter production ranging from 22,529 to $35,516 \mathrm{~kg} / \mathrm{ha}$ (Table 3). In the first group, the TNMP was over $37,000 \mathrm{~kg} / \mathrm{ha}$, emphasizing hybrid 866042 , which showed an average yield of $50,069 \mathrm{~kg} / \mathrm{ha}$. Rocha Júnior et al. (2000) found values of TNMP ranging from 11,500 to $49,000 \mathrm{~kg} / \mathrm{ha}$ on the genotype of high size, midsized, and down-sized plants.

Hybrid BRS 610, in the market for some time (Rodrigues Filho et al., 2006), showed total average production of natural matter of $35,516 \mathrm{~kg} / \mathrm{ha}$, lower than that found by Oliveira et al. (2005) of 63,140 kg/ha with $100 \mathrm{~kg}$ of nitrogen and 260-day cycle. Rodrigues Filho et al. (2006) found, coincidentally, that same value. This difference is probably due to average rainfall in these experiments, which was of $600 \mathrm{~mm}$, and the duration of the cycle, which was higher than those observed in this study.

The hybrid Volumax presented lowest average production. These results are superior to those found by Neumann et al. (2002), who found variations ranging from
22,707 to 39,563 kg/ha evaluating four sorghum hybrids (AGX-213, AG-2002, AGX-217, and AG-2005E). However, Rodrigues Filho et al. (2006), assessing the potential yield of four sorghum hybrids (BRS 610, CMSXS 762, BR 506, and BR 700), observed higher response than the one found in this study, with TNMP ranging from 45,870 to 67,560 , probably due to the environmental conditions of each study.

The TDMP results showed variation $(\mathrm{P}<0.05)$ from 7,679 to 20,948 kg/ha (average of 13,799 kg/ha): 1F305, BRS 610 and Volumax were the hybrids with lowest potential and hybrids 866041 and 866042 were the most productive (Table 3). These results may highlight the high yield potential of hybrids, with TDMP similar to those found in other studies (Neumann et al. 2002; Rodrigues Filho et al., 2006).

The genotypes evaluated showed high TDMP values, compared with those assessed by Neiva et al. (1999), for example, who found a TDMP ranging from 5,892 to $18,144 \mathrm{~kg} / \mathrm{ha}$ under irrigation. Most hybrids showed intermediate production, being around the overall average.

Studies performed in Brazil show that a high TDMP for sorghum plants harvested at maturity stage with grains in mealy and hard stages ranges from 14,000 to $18,000 \mathrm{~kg} / \mathrm{ha}$ (Chapman et al., 1992; Pereira et al., 1993). Cunha \& Lima (2010) evaluated 29 sorghum genotypes in Rio Grande do Norte state and observed a TDMP ranging from 4,500 to $26,100 \mathrm{~kg} / \mathrm{ha}$ at dough stage.

According to McDonald (1991), the plant DM content is important in the fermentation process, since this factor determines the type of fermentation developed into the silo. Some authors have not reported in their studies significant differences in fermentation characteristics among the maturation stages (Molina et al., 2002, Araújo et al., 2007). Faria Júnior et al. (2010), however, evaluated hybrid BRS610 in seven different maturity stages using the gas production technique, and concluded that the quality of silage was satisfactory, especially for the grains at mealy stage. Thus, it is sought to achieve maximum DM production that does not endanger fermentation and nutritive value of silages.

In general, most of the hybrids assessed can be considered as of high productivity of biomass if compared with other hybrids tested on ecological conditions more favorable than semiarid region of Paraiba, such as the regularity of rainfall. In this context, it is worth noting the climate of the period in which the experiment was conducted (Table 1). In April, approximately 56\% of the rainfall occurred before the experiment implementation, totaling 304.2, 308.0, and $389.4 \mathrm{~mm}$ for the first, second and third harvests, respectively.

Hybrids Volumax, BRS 610 and XBS60329 presented the lowest $(\mathrm{P}<0.05)$ mean values of TDMP, compared with 
hybrids means with TDMP of about 15,397. When compared with the assessment made by Gomes et al. (2006), in the state of Ceará, Brazil, Volumax showed average TDMP of 9,464 kg/ha, 20\% higher than the value observed in this study. Hybrids 1F305, Volumax, BRS 610, and XBS60329 are already available in the market and were used in the experiment as references for their agronomic characteristics. A fact that should be considered when assessing the means of TDMP is that hybrids Volumax, BRS 610, and XBS60329 showed no grains at the harvest period, indicating a possible attack from birds, due to the low tannin content in the grain. Consequently, the participation of the panicles of these hybrids in total DM was lower $(\mathrm{P}<0.05)$, compared with the others (Table 4).

The TDMP values observed in this study are possibly not related to the height, but the plant components, as panicle percentage in total DM (Table 4). However, correlation between TDMP and panicle was low (0.38). Hybrid 866042, of higher productivity, was not necessarily the one with the highest percentage of panicles in the DM. Nevertheless, it presented over $50 \%$ of this component in its composition (Table 4).

Table 4 - Means of the components of total dry matter (DM), leaf blade, stem, dead matter and panicle of 25 sorghum hybrids grown in the semiarid region of Paraiba

\begin{tabular}{lcccc}
\hline Hybrid & Leaf blade & Stem & Dead matter & Panicle \\
\cline { 2 - 5 } & \multicolumn{4}{c}{$\%$ total DM } \\
\hline 866005 & $5.20 \mathrm{~b} *$ & $35.39 \mathrm{~d}$ & 1.11 & $58.29 \mathrm{a}$ \\
866019 & $6.38 \mathrm{~b}$ & $33.26 \mathrm{~d}$ & 1.18 & $59.19 \mathrm{a}$ \\
866033 & $6.15 \mathrm{~b}$ & $42.74 \mathrm{c}$ & 1.18 & $49.93 \mathrm{~b}$ \\
866034 & $7.51 \mathrm{~b}$ & $36.37 \mathrm{~d}$ & 0.32 & $55.80 \mathrm{a}$ \\
866035 & $6.95 \mathrm{~b}$ & $47.24 \mathrm{c}$ & 0.48 & $45.33 \mathrm{~b}$ \\
866036 & $7.52 \mathrm{~b}$ & $40.89 \mathrm{c}$ & 0.81 & $50.79 \mathrm{~b}$ \\
866037 & $7.52 \mathrm{~b}$ & $36.70 \mathrm{~d}$ & 0.44 & $55.34 \mathrm{a}$ \\
866040 & $6.81 \mathrm{~b}$ & $32.29 \mathrm{~d}$ & 0.77 & $60.12 \mathrm{a}$ \\
866041 & $8.46 \mathrm{~b}$ & $37.59 \mathrm{~d}$ & 0.37 & $53.57 \mathrm{~b}$ \\
866042 & $6.91 \mathrm{~b}$ & $37.43 \mathrm{~d}$ & 1.50 & $54.16 \mathrm{~b}$ \\
866043 & $6.57 \mathrm{~b}$ & $41.32 \mathrm{c}$ & 0.63 & $51.48 \mathrm{~b}$ \\
866044 & $7.05 \mathrm{~b}$ & $22.95 \mathrm{~d}$ & 1.32 & $68.69 \mathrm{a}$ \\
870025 & $6.62 \mathrm{~b}$ & $31.89 \mathrm{~d}$ & 1.22 & $60.26 \mathrm{a}$ \\
870031 & $6.69 \mathrm{~b}$ & $30.39 \mathrm{~d}$ & 0.92 & $62.00 \mathrm{a}$ \\
870035 & $5.68 \mathrm{~b}$ & $33.25 \mathrm{~d}$ & 2.37 & $58.70 \mathrm{a}$ \\
870041 & $8.21 \mathrm{~b}$ & $34.75 \mathrm{~d}$ & 1.72 & $55.32 \mathrm{a}$ \\
870051 & $8.06 \mathrm{~b}$ & $34.07 \mathrm{~d}$ & 0.81 & $57.06 \mathrm{a}$ \\
870067 & $7.34 \mathrm{~b}$ & $32.74 \mathrm{~d}$ & 1.74 & $58.18 \mathrm{a}$ \\
870081 & $7.74 \mathrm{~b}$ & $41.96 \mathrm{c}$ & 0.56 & $49.74 \mathrm{~b}$ \\
870085 & $5.88 \mathrm{~b}$ & $34.29 \mathrm{~d}$ & 1.24 & $58.59 \mathrm{a}$ \\
870095 & $7.05 \mathrm{~b}$ & $34.56 \mathrm{~d}$ & 0.28 & $58.12 \mathrm{a}$ \\
1 F305 & $14.34 \mathrm{a}$ & $76.19 \mathrm{a}$ & 1.29 & $8.17 \mathrm{~d}$ \\
BRS 610 & $10.16 \mathrm{~b}$ & $72.84 \mathrm{a}$ & 1.51 & $15.49 \mathrm{~d}$ \\
Volumax & $14.60 \mathrm{a}$ & $62.60 \mathrm{~b}$ & 0.00 & $22.80 \mathrm{c}$ \\
XBS60329 & $14.21 \mathrm{a}$ & $61.55 \mathrm{~b}$ & 0.72 & $23.52 \mathrm{c}$ \\
Mean & 7.98 & 41.01 & 0.98 & 50.03 \\
CV (\%) & 15.05 & 11.93 & 73.22 & 9.43 \\
\hline
\end{tabular}

* Means followed by the same letter in column do not differ by Scott-Knott test at $5 \%$ probability, $\mathrm{CV}=$ coefficient of variation.
There were differences $(\mathrm{P}<0.05)$ between the mean of hybrids for all components of total DM (Table 4), except the percentage of dead matter. Hybrids 1F305, Volumax and XBS60329 showed higher $(\mathrm{P}<0.05)$ percentages of leaf in total DM. These hybrids with the highest percentage of leaves had higher $(\mathrm{P}<0.05)$ percentage of stem and lower $(\mathrm{P}<0.05)$ percentage of panicles in relation to others. However, in the stem the most soluble carbohydrates from the plant are observed, which are the main substrate for lactic fermentation, responsible for the proper forage preservation (Zanine et al., 2007).

The participation of stem ranged from 30 to $73 \% \mathrm{DM}$, with an average of 41.07\%. Hybrids 1F305 and BRS 610 showed the highest $(\mathrm{P}<0.05)$ values for the percentage of stem, followed by hybrids Volumax and XBS60329. Flaresso et al. (2000) consider the stem as the main component, responsible for producing silages of low nutritional value due to their low nutritional value.

The average percentage of dead matter showed no significant difference $(\mathrm{P}>0.05)$ among hybrids, probably due to the large variation of this variable within treatments and between blocks.

All hybrids, except for 1F305, Volumax, BRS 610, and XBS60329 showed over $50 \%$ of DM composed by panicles. According to Nussio (1992), 40 to 50\% of DM should be composed of grains at the time of ensiling, as a way to ensure quality to ensiled forage.

Currently, researchers have been trying to develop hybrids with good balance concerning stem, leaves and panicles, combining high DM production and high nutritive value. Given this, the hybrids are characterized as of dual purpose, since they have high productivity and high percentage of panicle. In a study conducted by Neumann et al. (2002), these authors found much lower percentages of stem for the dual-purpose hybrid AG2005E (33.4\%).

Panicle and leaves of the plant have a higher total digestibility coefficient (Flaresso et al., 2000; Neumann et al., 2002). The higher percentage of panicle, besides contributing to the increase in silage quality, in terms of its nutritive value, still has a very large participation in the percentage of dry matter of ensiled material, due to the lower water content (Zago, 1991).

Hybrids were grouped in a hierarchical way by the Ward method, based on the characteristics of plant height, TNMP, TDMP, leaf blades, stems and panicles. Those which presented a greater relative contribuition were TNMP, TDMP and panicle, with values of 33,14 , and $26 \%$ respectively. Thus, the 25 hybrids were divided into four groups, heterogeneous among themselves, but with intra 
group homogeneity, based on the dissimilarity expressed by the average Euclidean distance (Figure 2).

In the dendrogram of Figure 2, a cut was made in a subjective way, as in Johnson \& Wichern's experiment (1992), considering $50 \%$ of dissimilarity, resulting in the hierarchical establishment of four groups. Two major groups were formed containing 21 of the hybrids studied, and two more groups with commercial hybrids used. These last two groups are in an average Euclidean distance of 14.64 compared to other hybrids. It is possible to observe a greater variability within the groups, indicating that, within these, some hybrids may stand out as for the characteristics assessed.

For the variable height of the plant, groups 1, 2, and 3 presented mean values around $2.0 \mathrm{~m}$, with little variation within the groups. However, the maximum values of groups 1 and 2 were 2.26 and $2.13 \mathrm{~m}$, respectively. The fourth group, formed by hybrid 1F305, showed an average plant height $28 \%$ higher than the averages of groups 1,2 , and 3 (Table 5 ).

Group 1, composed of $48 \%$ of the hybrids under study, along with group four (hybrid 1F305), presented intermediate mean values of TNMP and TDMP. Together, the means of these groups were 39.3 and $52.2 \%$ higher than those of group 3 and 26.7 and $31.6 \%$ lower than in group 1 , for TNMP and TDMP, respectively. However, when considering the minimum and maximum values of each group, the minimum values of these productions of group 1 approach the maximum values of group 3, the same way as the maximum TNMP and TDMP of the group 1 approach the minimum values of

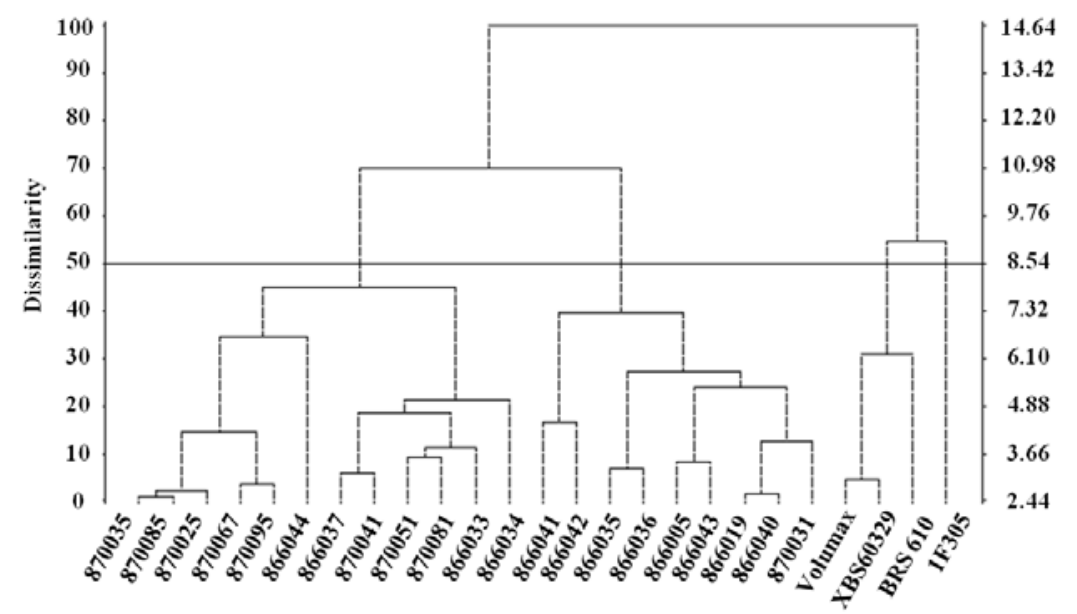

Figure 2 - Dissimilarity dendrogram based on agronomic characteristics of 25 hybrids sorghum.

Table 5 - Descriptive statistics of the agronomic characteristics of the groups consisting of 25 sorghum hybrids

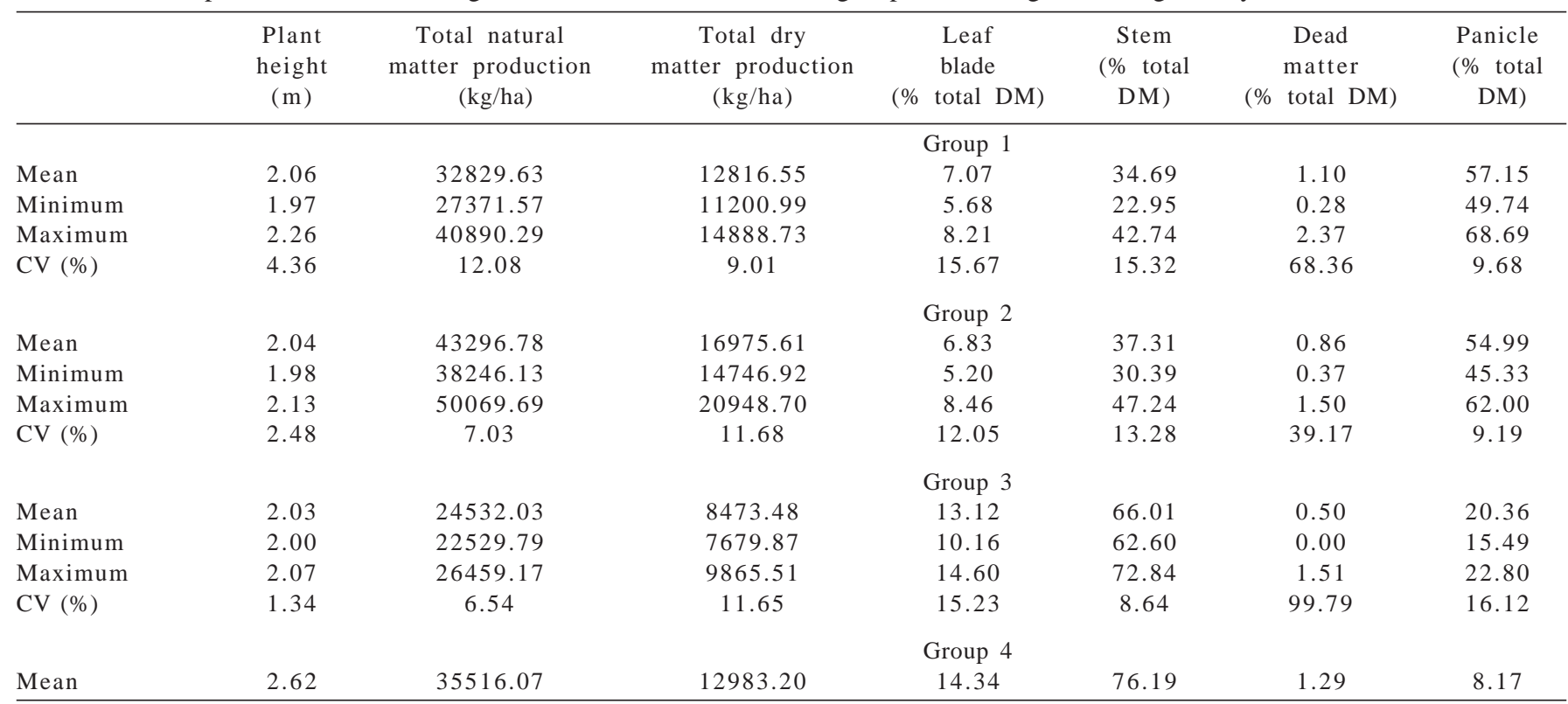

$\mathrm{CV}=$ coefficient of variation. 
group 2 and may even exceed its value, as in TNMP, which the maximum value of group 1 is greater than the minimum of group 2. These amplitudes compose the variation within groups, which, in this experiment, was low.

Similar behavior was observed for TDMP, since hybrids of groups 1 and 4 had intermediate mean values, and group 2 , an average higher than the others. In spite of being latematuring, hybrid 1F305, from group 4, showed production similar to those of some hybrids from group 2. In this sense, it is noteworthy that the average total DM production of hybrid 1F305 (12,983 kg/ha) was higher than 7,072 kg/ha, observed by Silva et al. (2007) using fertilizer, 16, 40 and $40 \mathrm{~kg} / \mathrm{ha}$ for N, P, and K, respectively, in the southwestern of Goias state, Brazil.

Within group 2, hybrids 866041 and 866042 formed a subgroup that presents the highest means of TDMP, a fact that should be considered when analyzing the group as a whole (Figure 2). These values are important in determining the cost of production, since hybrids of increased production show a lower cost per ton of DM ensiled (Neumann et al., 2003).

Group 3, composed of hybrids Volumax, BRS 610, and XBS60329, presented the lowest mean to the production characteristics and the lowest percentage of panicle compared with groups 1 and 2 .

Groups 1 and 2 (84\% of hybrids) showed a higher percentage of the panicles in the total DM and, hence, lower values of leaf blades and stem, characterizing these hybrids as of dual purpose. Hybrids belonging to groups 3 and 4 showed a lower percentage of panicles and larger amount of leaf blades and stems in total DM.

In general, the hybrids under study combine the features of high production with high percentage of panicle in the DM, which is the desirable in a breeding program and for the production of silage with high nutritional value. These hybrids, being in test phase, were adapted to semiarid conditions and can be an important source of food preserved as silage during the dry season.

Thus, the findings in this study suggest, based on agronomic characteristics, that hybrids belonging to groups 1 and 2 showed adaptation to the edaphoclimatic conditions of the semiarid region of Paraiba. Hybrids 866041 and 866042 showed the highest production values of total DM: $19.685,18$ and $20.948,70 \mathrm{~kg} / \mathrm{ha}$, respectively.

\section{Conclusions}

Hybrids 870081, 866033, 870041, 866037, 866034, 870051, 870067, 870095, 870085, 870035, 870025, 866044, 866035, 866036, 866042, 866043, 866041, 866005, 866019, 866040,
870031, and 1F305 show adaptability to the edaphoclimatic conditions of the semiarid region of Paraíba state. Hybrids 866041 and 866042 presented a high potential for dry matter production. For a final recommendation, further assessments are needed in other environments in the semiarid region of Paraíba state.

\section{References}

ARAÚJO, V.L.; RODRIGUEZ, N.M.; GONÇALVES, L.C. et al. Qualidade das silagens de três híbridos de sorgo ensilados em cinco diferentes estádios de maturação. Arquivo Brasileiro de Medicina Veterinária e Zootecnia, v.59, n.1, p.168-174, 2007. CARVALHO, D.D.; ANDRADE, J.B.; BIONDI, P. et al. Estádio de maturação na produção e qualidade da silagem de sorgo. I. Produção de matéria seca e da proteína bruta. Boletim Indústria Animal, v.49, n.2, p.91-99, 1992.

CUNHA, E.E.; LIMA, J.M.P. Caracterização de genótipos e estimativa de parâmetros genéticos de características produtivas de sorgo forrageiro Revista Brasileira de Zootecnia, v.39, n.4, p.701-706, 2010.

FLARESSO, J.A.; GROSS, C.D.; ALMEIDA, E.X. Cultivares de milho e sorgo para ensilagem no Alto Vale do Itajaí, Santa Catarina. Revista Brasileira de Zootecnia, v.29, n.6, p.1608-1615, 2000.

FARIA JÚNIOR, W.G.; GONÇALVES, L.C.; MAURÍCIO, L.C. et al. Avaliação das silagens do sorgo BRS-610 em sete estádios de maturação pela técnica in vitro semiautomática de produção de gases. Arquivo Brasileiro de Medicina Veterinária e Zootecnia, v.62, n.4, p.898-905, 2010.

GOMES, S.O.; PITOMBEIRA, J.B.; NEIVA, J.N.M. et al. Comportamento agronômico e composição químico-bromatológico de cultivares de sorgo forrageiro no Estado do Ceará. Revista Ciência Agronômica, v.37, n.2, p.221-227, 2006.

JOHNSON, R.A.; WICHERN, D.W. Applied multivariate statistical analysis. 3.ed. New Jersey: Prantice Hall, 1992. 642p.

McDONALD, P.; HENDERSON, A.R.; HERON, S. The biochemistry of silage. 2.ed. Marlow: Chalcombe, 1991.340p.

MELLO, R.; NÖRNBERG, J.L.; ROCHA, M.G. et al. Análise produtiva e qualitativa de um híbrido de sorgo interespecífico submetido a dois cortes. Revista Brasileira de Milho e Sorgo, v.2, n.1, p.20-33, 2003.

MOLINA, L.R.; GONÇALVES, L.C.; RODRIGUEZ, N.M. et al. Qualidade das silagens de seis genótipos de sorgo (Sorghum bicolor (L) Moench) em diferentes estádios de maturação. Arquivo Brasileiro de Medicina Veterinária e Zootecnia, v.54, n.2, p.159-168, 2002.

MONTEIRO, M.C.D.; ANUNCIAÇÃO FILHO, C.J.; TABOSA, J.N. et al. Avaliação do desempenho de sorgo forrageiro para o semiárido de Pernambuco. Revista Brasileira de Milho e Sorgo, v.3, n.1, p.52-61, 2004.

NEIVA, J.N.M.; OLIVEIRA, J.F.; SOUZA, M.L.O. et al. Produção de cultivares e híbridos de sorgo (Sorghum bicolor L. Moench) cultivados em áreas irrigadas do Ceará. In: REUNIÃO ANUAL DA SOCIEDADE BRASILEIRA DE ZOOTECNIA, 36., 1999, Porto Alegre. Anais... Porto Alegre: SBZ, 1999. (CD-ROM).

NEUMANN, M.; RESTLE, J.; ALVES FILHO, D.C. et al. Avaliação de diferentes híbridos de sorgo (Sorghum bicolor, L. Moench) quanto aos componentes da planta e silagens produzidas. Revista Brasileira de Zootecnia, v.31, n.1, p.302-312, 2002 (supl.)

NEUMANN, M.; RESTLE, J.; BRONDANI, I.L. et al. Comportamento produtivo e custo de produção de híbridos de sorgo (Sorghum bicolor, L. moench) para silagem. Revista Brasileira de Milho e Sorgo, v.2, n.3, p.43-54, 2003. 
NUSSIO, L.G. Produção de silagem de alta qualidade. In: REUNIÃO NACIONAL DE MILHO E SORGO, 19., 1992, Porto Alegre. Anais... Porto Alegre: SAA, 1992. p.155-175.

OLIVEIRA, R.P.; FRANÇA, A.F.S.; FILHO, O.R. Características agronômicas de cultivares de sorgo (Sorghum bicolor (L.) Moench) sob três doses de nitrogênio. Pesquisa Agropecuária Tropical, v.35, n.1, p.45-53, 2005.

PEREIRA, O.G.; OBEID, J.A.; GOMIDE, J.A. et al. Produtividade de uma variedade de milho (Zea mays L.) e de três variedades de sorgo (Sorghum bicolor (L.) Moench) e o valor nutritivo de suas silagens. Revista Brasileira de Zootecnia, v.22, n.1, p.31-38, 1993.

PORTUGAL, A.F.; ROCHA, V.S.; SILVA, A.G. et al. Rendimento de matéria seca e proteína de cultivares de sorgo forrageiro no primeiro corte e na rebrota. Revista Ceres, v.50, n.289, p.357-366, 2003.

REZENDE, P.M.; SILVA, A.G.; GRIS, C.F. Consórcio sorgo-soja. XII. Produção de forragem de cultivares de soja e híbridos de sorgo consorciados na entrelinha em dois sistemas de corte. Revista Ceres, v.52, n.299, p.59-71, 2005.

ROCHA JÚNIOR, V.R.; GONÇALVES, J.C.; RODRIGUES, J.A.S. et al. Avaliação de sete genótipos de sorgo (Sorghum bicolor (L.) Moench) para produção de silagem. II - Padrão de fermentação. Arquivo Brasileiro de Medicina Veterinária e Zootecnia, v.52, n.5, p.12-18, 2000.

RODRIGUES FILHO, O.; FRANÇA, A.F.S.; OLIVEIRA, R.P. et al. Produção e composição bromatológica de quatro híbridos de sorgo forrageiro [Sorghum bicolor (L.) Moench] submetidos a três doses de nitrogênio. Ciência Animal Brasileira, v.7, n.1, p.37-48, 2006.

SANTANA, C.M.; MALINOVSKI, J.R. Uso da análise multivariada no estudo de fatores humanos em operadores de motosserra. Cerne, v.8, n.2, p.101-107, 2002.

SANTOS, C.; FERREIRA, D.F.; BUENO FILHO, J.S.S. Novas alternativas de testes de agrupamento avaliadas por meio de simulação Monte Carlo. Ciência e Agrotecnologia, v.25, n.6, p.1382-1392, 2001.

SCOTT, A.J.; KNOTT, M. A cluster analysis method for grouping means in the analysis of variance. Biometrics, v.30, p.507-512, 1974

SIEGMUND, K.D.; LAIRD, P.W.; LAIRDOFRINGA, I.A. A comparison of cluster analysis methods using DNA methylation data. Bioinformatcs, v.20, n.12, p.1896-1904, 2004.

SILVA, D.F.; SILVA, A.M.A.; LIMA, A.B. et al. Exploração da caatinga no manejo alimentar sustentável de pequenos ruminantes. In: CONGRESSO BRASILEIRO DE EXTENSÃO UNIVERSITÁRIA, 2., 2004, Belo Horizonte. Anais... Belo Horizonte, 2004. p.8.

SILVA, A.G.; BARROS, A.S.; TEIXEIRA, I.R. Avaliação agronômica de cultivares de sorgo forrageiro no sudoeste do estado de Goiás em 2005. Revista Brasileira de Milho e Sorgo, v.6, n.1, p.116-127, 2007.

TABOSA, J.N.; FRANÇA, J.G.E.; SANTOS, J.P.O. et al.Teste em linhas de sorgo no semi-árido de Pernambuco para consumo humano. Pesquisa Agropecuária Brasileira, v.28, n.12, p.1385-1390, 1993.

TABOSA, J.N.; REIS, O.V.; BRITO, A.R.M. et al. Comportamento de cultivares de sorgo forrageiro em diferentes ambientes agroecológicos dos estados de Pernambuco e Alagoas. Revista Brasileira de Milho e Sorgo, v.1, n.2, p.47-58, 2002.

UNIVERSIDADE FEDERAL DE VIÇOSA - UFV. Sistema de análises estatísticas e genéticas - SAEG. Versão 8.0. Viçosa, MG, 2000. 142p.

ZAGO, C.P. Cultura do sorgo para produção de silagem de alto valor nutritivo. In: PEIXOTO, A.M.; MOURA, J.C.; FARIA, V.P. (Eds.) SIMPÓSIO SOBRE NUTRIÇÃO DE BOVINOS, 4. 1991, Piracicaba. Anais... Piracicaba: Fundação de Estudos Agrários “Luiz de Queiroz”. 1991. p.169-217.

ZANINE, A.M.; SANTOS, E.M.; FERREIRA, D.J. et al. Populações microbianas e nutricionais nos órgãos do capim-tanzânia antes e após a ensilagem. Ciências Agrárias, v.28, n.1, p.143-150, 2007. 